\title{
QURANIC EXEGESIS AS SOCIAL CRITICISM: The Case of Tafsîr al-Azhâr
}

\author{
Ilyas Daud
}

Institut Agama Islam Negeri Sultan Amai Gorontalo, Indonesia

E-mail: yasieselebes@gmail.com

\section{Abstract}

This paper examines one of Nusantara commentary books entitled Tafsir alAzhâr that is written by Hamka. By analyzing the contents of the commentary and tracing the historical roots of the birth of the work, this study shows that Hamka contextualises his interpretation as a criticism against the Sukarno regime. Among the critiques that he poses in his commentary suggest that Sukarno aligns to communism and the political policies of his administration resonate to the interest of Communist while at the same time are detrimental to that of Muslims. From the historical perspective, there was, in fact, a conflict between Hamka and Sukarno concerning the issue of communism. In other words, there is a close relationship between Sukarno's affinity to communism and Muslim's conflict with Communists in Indonesia. In the development of tafsîr studies so far, tracing the interpretation material in the context of social criticism is considerably understatement. This is the reason why this study takes this approach. This study suggests that tafsir (Quranic exegesis) is not just a task of understanding the divine message, but can also be a social critic.

Tulisan ini mengkaji salah satu kitab tafsir Nusantara, yaitu Tafsîr alAzhâr karya Hamka. Dengan analisis isi pada materi tafsir dan melacak akar historis kelahiran tafsir, penelitian menunjukkan bahwa Hamka mengkontekstualisasikan tafsirnya sebagai kritik atas rezim Sukarno. Diantara kritik dalam tafsirnya menyebut Sekarno adalah bagian dari 
Komunis dan kebijakan politik pemerintahannya memggambarkan kepentingan komunisme dan pada saat yang sama merugikan umat Islam. Dari sudut pandang historis, memang secara fakta pernah terjadi konflik antara Hamka dan Soekarno mengenai isu komunisme. Dalam kata lain, ada hubungan yang erat antara kedekatan Sukarno dan komunisme dengan konflik antara umat Islam dengan Komunis di Indonesia. Dalam perkembangan studi tafsir selama ini, melacak materi tafsir dalam konteks kritik sosial hampir tidak teramati oleh para pengkaji tafsir. Inilah alasan mengapa tulisan ini mengambil pendekatan ini. Kajian ini membuktikan bahwa tafsir bukanlah hanya tugas memahami pesan ilahi, tetapi juga bisa menjadi kritik sosial.

Keywords: criticism; Hamka; Sukarno; Tafsîr al-Azhâr

Received: October 16, 2019; Accepted: April 14, 2020

\section{Introduction}

Tafsîr is usually defined as an activity to unveil the meaning of God's message that is hidden behind the words and sentences of the Quran. In the belief of Muslims, tafsir is considered a holy activity, because, in addition to being an effort to understand the message of God, it is also an effort to show people the right path and salvation (Jamarudin, May, and Pudin 2019, 24-26). Following the development of science and human thought, historical awareness begins to influence the way Muslims, especially commentators, understand the Quran (Bahary 2015, 177; Hakim 2018, 26-27). Not only do they serve as the translators of the tangible language of God written in the Quran, but they are also part of the social life who have social responsibilities.

Against this backdrop, one particular genre of tafsîr makes social context as one of the exegetical materials (Zulaiha 2017). The commentary books of this style contain materials in which authors pose their criticisms of the socio-political conditions, including Tafsîr al-Azhâr. This paper explores further the Quranic exegeses as social criticism in the Tafsir al Azhâr of Hamka. More specifically, this article deals with Hamka's criticism of the Sukarno regime.

Sukarno regime referred to in this paper is a regime that corroborates with communism, while according to Hamka, Sukarno 
represents the communists in Indonesia. From a historical perspective, this tafsitr was written during the period of proliferation of communism in Indonesia, which was between 1958 and the 1960s. Even more, the birth of Hamka coincides as well with another era of communism in Indonesia. Thus, the influence upon his interpretation of the Quran is not only seen in the context of the time the work was written, but it covers as well the period long before the interpretation would appear. Citing from H. G. Gadamer, Sahiron Syamsuddin suggests that a mufassir will always carry his horizon in the form of past experiences when dealing with texts and those experiences also determine the direction of interpretation (Syamsuddin 2009, 45). Hence, this study analyzes Tafsîr al-Azhâr on two stages: firstly, the content of interpretations that contain criticisms against the Sukarno regime and, secondly, the socio-historical context as the root of interpretation. Furthermore, the two steps are linked from which conclusion are drawn.

As far as I am concerned, this theme is relatively understudied: there has never been writing that employ this perspective. Perhaps one that is a little closer to this approach is Ulya's dissertation entitled Hubungan Kekuasaan-Pengetahuan Dalam Pewacanaan Ûlu Al-Amr QS. An-Nisa' (4) Pada Tafsîr al-Azhâr: Memotret Diskusi Negara Indonesia Tahun 1955-1966 (Ulya 2015). However, Ulya's research only traces the way the interpretation of Q.S. alNisâ' [4]: 59 in Tafsîr al-Azhâr is practised by the reader of the commentary, instead of content analysis that is framed as social criticism that correlates it with the socio-historical context of the birth of the commentary. Besides, the topic investigated by Ulya does not concern with the Sukarno regime. After an observation upon the differences in the position of this paper with other writings, it is expected that it provides its novelty.

\section{Map of Hamka's Intellectual}

Hamka (Haji Abdul Malik Karim Amrullah) is one of the leading and most interesting figures of the 20th century Indonesia. He was a Muslim scholar and activist. Hamka was born in Minangkabau, West Sumatra in 1908 to a family of religious and Sufi leaders. His father, Shaykh Abdul Karim Amrullah (1879-1945), was a religious figure who was influenced by reformist ideas from the Arab world (Pink 2010a, 22). This influence brought Shaykh Abdul Karim Amrullah as a pioneer of the Islamic reform movement in Minangkabau (Ilyas 2006, 27; Hamka 1983, $\mathrm{xv})$. 
Hamka's education covered both religious and secular sciences. Around 1927, he started to join the Muhammadiyah organization, which is engaged in the Islamic social sector, education, the welfare of the Ummah. He also served as a journalist and a lecturer. In 1950 Hamka moved to Jakarta and became a respected central figure in al-Azhar mosque. He then joined an Islamic party, Masyumi, and became one of the prominent members. In 1960, the Masyumi party was dissolved, and in 1964, Hamka was jailed for two years. It was during this time that he wrote the commentary on al-Azhar (Pink 2010a, 22).

Hamka is a multidimensional ulama, as reflected in the honorary titles he bears. He holds the title "Datuk Indomo" by which, in the Minangkabau tradition, he plays a role as a figure who preserves customs. In a Minang proverb, the customary provisions which must persist are said to be "sebaris tidak boleh hilang, setitik tidak boleh lupa" (one line that must not disappear, one point that must not be forgotten). This title is an inheritance from the Minangkabau custom he got from his grandfather from his mother's lineage; Engku Datuk Rajo Endah Nan Tuo, Head of the Tanjung tribe. Then as a Minang ulama, Hamka was dubbed "Tuanku Shaykh", meaning the great ulama who has the authority of membership in a customary meeting with the position of Imam Khatib according to Budi Chaniago's custom (Hamka 1982a, 5). As a warrior, Hamka obtained the honorary title of "Pangeran Wiroguno" from the Government of the Republic of Indonesia.

Hamka was a prolific writer. His writings cover Islamic scientific works and fiction such as novels and short stories. In 1928, Hamka wrote his first romance book in Minangkabau entitled "Si Sabariah." Furthermore, he also wrote in other genres, including romance, history, biography and autobiography, social, thought and education, theology, Sufism, interpretation, and figh. In total, he wrote at least 300 titles, both large and small books. His most significant work is Tafsîr al-Azhâr.

In 1958, Hamka, as an Indonesian well-known writer and scholar, was awarded the Honorary Doctorate Degree by the al-Azhar University (Keener 2002, 91). This title was given for his services in preaching Islam using the Malay language. In the history of al-Azhar, Hamka is the fourth figure to receive the title. Previously, al-Azhar, as one of the oldest universities in the world, had awarded H.C. to Abdul Karim Amrullah in 1926, father of Hamka, together with Buya Abdullah Ahmad from Padang. 
The third figure to achieve this title was Rahmah el-Yunusiah from Diniyah Putri Padang Panjang in 1957. Thus, in the history of al-Azhar, father and son that received the title of Doctor of H.C. are from Indonesia; Hamka and his father. In 1974 he obtained a similar degree from the University of Kebangsaan Malaysia. At the graduation ceremony at the Malaysian Parliament building, Tun Abdul Razak, Chancellor of the University of Kebangsaan, who was then serving as Prime Minister called it "Promovendus Professor Doctor Hamka". Then he obtained the title of Professor from the University Prof. Dr. Moestopo (Hamka 2013, xix).

From 1951 to 1960, he served as Pegawai Tinggi Agama (High Religion Officer) by the Indonesian Minister of Religion. Nevertheless, he laid down that position when Sukarno told him to choose between being a civil servant or active in politics in the Indonesian Syuro Muslim Council (Masyumi). With his high Arabic language proficiency, he was able to investigate the work of great scholars and poets in the Middle East such as Zakî Mubârak, Jurjî Zaydân, 'Abbâs al-Aqqâd, Musțafâ al-Manfalutî, and Hussayn Haykal. It is through his Arabic competency as well he encountered with writings produced in French, English, and German scholars. He was a great reader and a great discussion partner to famous Jakarta figures such as HOS Tjokroaminoto, Raden Mas Soerjopranoto, Haji Fachrudin, AR Sutan Mansur, and Ki Bagus Hadikusumo. Those experiences rewarded him the ability to become a great orator (Ismatulloh 2015, 160).

Hamka's intellectual projection leads to efforts to enlighten the people. This can be observed from his work, such as Tafsîr al-Azhâr. He admitted that his interpretation was highly influenced by the idea of reform initiated by Jamâl al-Dîn al-Afghânî, Muhạmmad 'Abduh, and Rashîd Rị̂â. Hamka even compiled a particular book about the struggle of Jamâl al-Dîn al-Afghânî that contains a special chapter on al-Afghânî efforts in fighting colonialism, tyranny and ignorance among Muslims community (Hamka 1981, 60-65).

\section{Tafsîr al-Azhâr: History of Writing and Its Content}

Tafsîr al-Azhâr is a monumental work of Buya Hamka. This commentary started as a serial preaching sets after subh in the Great Mosque of al-Azhar Kebayoran Baru, in 1958. The first sûrah preached was sûrah alKahf, juz' XV. The content of the preaching was further rearranged and adjusted into written form, published periodically in the magazine Gema 
Islam since 1962. The consistent publication lasted to two years, and then halted following the arrest of Hamka on January 27, 1964; practically both serial tafsîr circles in the Great Mosque of al-Azhar and its publication in the magazine Gema Islam stopped.

Nevertheless, he continued writing his commentary in detention. He informed that the writing of his commentary had completed several days before being transferred to house arrest. During the period of house arrest, he spent two months to revisit his commentary and add what was deemed lacking (Hamka 1982b, vol. 1, 46).

Tafsîr al-Azhâr was first published by the Pembimbing Masa Publisher, led by H. Mahmud. This first publishing saw the printing of the first to the fourth juz'. Pustaka Islam Surabaya published juz' 15 to juz' 30, and juz' 5 to juz' 14 was published by the Nurul Islam Jakarta Foundation. Tafsir al-Azhâr was also published in Singapore and Kuala Lumpur Malaysia. Now Tafsîr al-Azhâr is published in full by Panjimas Pustaka Publisher Jakarta. There are at least two reasons why Buya Hamka entitled his commentary Tafsîr al-Azhâr. First, the interpretation starts from serial preaching set at the al-Azhar Great Mosque in Jakarta, the name given directly by the al-Azhar University Shaykh of Cairo, Shaykh Mahmûd Shaltût, in 1960. Second, Buya Hamka was awarded the Honoris Causa Doctorate from the University of Cairo al-Azhar Cairo (Hamka 1982b, vol. $1,46)$.

The sources used by Hamka in interpreting the Quran is, first of all, the Quran itself, working under the principle of interpretation of verses with other verses, and the prophet traditions (al-tafsîr bi al-ma'thîr). Also, Hamka uses historical, anthropological, and sociological materials to enrich his interpretation. The style and tendency of his commentary, to use the terminology of al-Farmâwî, is called tafsîr al-adab al-ijtimâ $\hat{\imath}$ (social-literary commentary). Such a style is carried out by Muhammad 'Abduh, and Rashîd Rị̂a in compiling al-Manâr's Interpretation. Hamka himself admits that he imitates al-Manâr's style of interpretation, in which the interpretation, besides describing knowledge related to religion, hadith, fiqh, history and so on, also explains the verses in the light of socio-political dynamic during the production of the commentary. For example, Hamka's interpretation reflects how the colonial era experience had a significant influence on the content of his interpretation (Pink 2010b, 44). 
There are similarities between Tafsîr al-Azhâr and Tafsîr al-Manâr concerning the process of their production. Both tafsîr were started from serial lectures in front of the congregation, which were then adjusted to written form. As a result, their interpretations are communicative in nature and close to the atmosphere and actual problems that were being faced by the community during the formation phase. Of course, this is not to ignore the different regional setting where the commentaries were produced; Tafsir al-Manâr was born from the background of Egyptian society, while Tafsîr alAzhâr was written within the context of Indonesian society. Therefore, Tafsîr al-Azhâr uses simple language that is easily understood by people from all walks of life. This is understandable, as the interpretation was arranged following the needs of the community itself, even the very interpretation is a response to the problems they are facing.

Hamka's Tafsîr al-Azhâr in Howard M. Federspiel's categorization belongs to the third generation of commentaries, that is the commentaries that aim at providing comprehensive explanation upon the words of God, and hence, contain materials related to text and methodology in analyzing tafsîr. In terms of the method, the interpretation of al-Azhâr can be categorized as tafsîr tahlîlî̀ (Kusnadi 2015, 4).

Federspiel further adds that among the archipelagic commentaries (Tafsir Nusantara), only Tafsîr al-Azhâr discusses the historical context of the verses of the Quran and its relation to contemporary events (Federspiel 1996, 48). Therefore, in Tafsîr al-Azhâr, Hamka seems to demonstrate the breadth of his knowledge in almost all disciplines of Islamic religious fields as well as non-religious knowledge (Faiz 2002, 73).

\section{Contextualization of Tafsîr}

In Tafsîr al-Azhâr, Hamka always links his criticism against Sukarno to his communism. This creates an impression that the main reason for this resistance was because Sukarno was a communist. Hamka accused Sukarno of being a communist in Indonesia (Hamka 1982b, vol. 1, 138-9). He also adds that Sukarno liked to mock religious people as kolot (old-fashioned) and fanatics (Hamka 2002, 27). In Tafsîr al-Azhâr, there are not a few verses that are contextualized as criticism against the Sukarno regime for his supports over communism.

This section elaborates on Hamka's resistance outlined in his interpretation. His commentary starts with interpretation over the literal 
meaning of the verse, and Hamka contextualises his commentary as his criticism against the communist regime in Indonesia represented by Sukarno. Hence, before contextualizing his interpretation, Hamka deals with the textual level of the verse (lughawi and intertext) and that of contextual (asbâb al-nuzûl). Therefore, although the main object of this study concerns with the contextual level of his interpretation, i.e. the structure of the resistance interpretation, this study will have to deals firstly with his interpretation at the textual level.

The clash between Hamka and Sukarno was at its very height when he was jailed and charged with treason or rebellion. Hamka felt he had been slandered on those charges. Hamka himself admitted that it was very hurtful, as he thought it was impossible to betray his homeland.

This accusation, according to Hamka, resembles the experience of the Prophet Muhammad as mentioned by the Quran in the Q.S. al-An'âm [6]: 33:

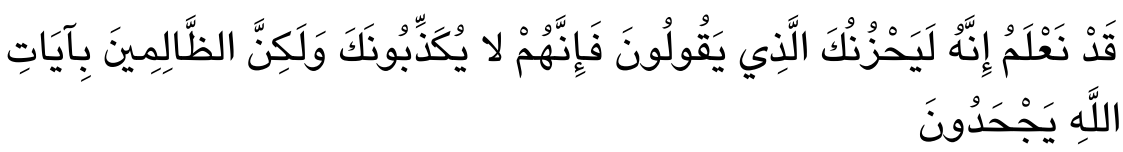

"We know well that what they say grieves you (Prophet), It is not you they disbelieve: the evildoers reject God's revelation."

The Prophet felt sorrow over the accusations of unbelievers. They accuse the Prophet Muhammad of witchcraft and lying (al-Khawârizmî $2009,329)$. He was sad not because he was offended, but for what he saw in his community that they remained to love darkness and reject the bright light. Though the Prophet Muhammad grew as a man with high integrity from his childhood, his communities suddenly denied him after he had received revelation. Indeed, those insult hurt his feeling.

Hamka appropriated this particular story of Prophet Muhammad explaining inconvenience he felt for the accusations of Sukarno. He writes as follows:

"The author of this commentary experienced something bitter during hostile detention and investigation by the police, in a time when Indonesia started to leave the value of justice because the head of the state was imposed with no-God-ism (communism). Suddenly (I) was continuously questioned for nearly a month; various made-up charges by the police were imposed to deceive the author of Tafsîr al-Azhâr. When I 
answered their questions honestly, they immediately rejected them harshly, yielding: "You are lying!" Accused of lying, for the author, hurts far more than being hit or shot. That is one of the reasons the author had been a bit deaf after getting out of prison. Whereas for us, ordinary people, who in themselves have grown a good sense of honesty and accountability before God, the accusation of lying hurts much, let alone for the Prophet. Let alone for the Prophet Muhammad. (It is upon) this matter God heals, "Do not you mourn! It's not you that they lied to, but I am. Because the revelation that you speak with is from Me" (Hamka 1982b, vol. 3, 179).

The vilification that embodies the tyrannical nature of the communist authority made Hamka in dire need of God's help. He was very confident that the help will come. When interpreting Q.S. al-Baqarah [2]: 214 that concerns with the help of Allah to the prophets and messengers and the believers after they have experienced hardships, accidents and shocks, Hamka contextualizes it with what he experienced about the hostility of communism. He recounts in his commentary that at the time of the communist rule in 1965 (1385 Hijriyah), during which he was a prisoner for the defamation by the communist authorities, one of his children asked: "Father! Is it true that Allah will help believers? Does not God's help deservedly come now? Hamka recited the Q.S. al-Baqarah [2]: 214 to his son. Then God's help came. He wrote as follows:

"But what happened next? Who could expect that God destines it very easily that the fall of communism was due to their careless moves? After this occasion, I truly convinced with the interpretation of this verse" (Hamka, 1982b, vol. 1, 174-5).

Hamka also links the fall of communist authority for their tyranny to Q.S. al-An'âm [6]: 45:

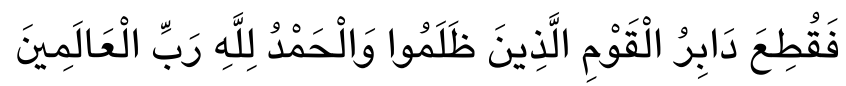

"The evildoers were wiped out: praise be to God, the Lord of the Worlds!"

The verse talks about Allah's warning to the Prophet Muhammad as well as the message of the Prophet Muhammad to his people that his followers shall not be fascinated to see unbelievers and reject the truth of Allah in the form of doing anything they please in the lands; because all of 
that is just a limited opportunity. The place that was available to them is hell.

Hamka contextualizes the meaning of the above verse with the communist tyranny in Indonesia that ended up a failure. In Tafsîr al-Azhâr, he warns that so many people stray out of the right path and forget that the Mighty Allah may turn the situation around. It is wrong to give meaning to independence by claiming total freedom following lust to the extent that is disregarding the border determined by Allah. After the independence of Indonesia, the people would surely expect prosperity and justice, yet what happened was that prosperity became the exclusive affairs of a limited people, those who sold their faith to wrongdoers (zalim). Furthermore, Hamka writes:

"... And by using the name Democracy the unjust authority carried out the Autocracy's orders. A human being appoints himself to be God. If someone gives an honest warning, (he) is accused of being an enemy of the state and persecuted, tortured, exiled and imprisoned. This injustice cannot be stood against" (Hamka 1982b, vol. 3, 196-7).

Hamka explained that during this kind of situation, many people had lost their patience in expecting God's promises. Eventually, beyond human expectations whatsoever, the tyrant fell, the seeds planted by those people were cut off by God and uprooted.

The unjust authority (orang zalim) referred to in the above interpretation are Sukarno and his supporting communists, as written in a footnote as follows:

"I wrote this (part of) commentary at the end of April 1965. (It was during this time) culminated the tyrannical authority of Sukarno who had colluded with the communists to uphold the tyrannical governance. And I was in detention. And at that time there was no sign of how I could get out of this prison whatsoever. I kept this commentary with the hope that someday the power of this unjust people would eventually end; Sukarno's administration would fall or he himself would die. I asked my children to keep this commentary safe and release it for publication after Sukarno's rule have stepped down. Nevertheless, beyond my expectation, and beyond Sukarno's expectation, on 30 September 1965, God's decision comes all of a sudden. Sukarno falls, and the seeds of communism that have supported his power are cut off by God, and I came out safely from that persecution, and this commentary came out without having to be kept for long or smuggled in to be printed" (Hamka 1982b, vol. 3, 197). 
Hamka links the failure of the communists in Indonesia during their attempt at seizing power with their arrogance, through PKI, for the belief of their powers and rejection over God's might. This kind of contextualization occurs in his interpretation upon Q.S. Âli 'Imrân [3]: 29. The verse talks about the might of God that knows what within the chest of people. God will definitely discover any deed or secret that is hidden. And Allah is well aware of the contents of the human chest and even the secrets of heaven and earth (al-Tabarî 1994, vol. 2, 243-4).

With regards to this verse, Hamka explains that sometimes there is a strong connection between the contents of the human heart and the secrets of heaven and earth, in the sense that God's power exceeds that of human, thus, whatever people have planned is determined by God's destiny. Humans might be planning something, but God can frustrate it. It is this message that Hamka underlines in his criticism against communists who, he thinks, feel as if they have power and reject the might of God.

Hamka contextualizes his interpretation to criticize Sukarno that one day an arrogant head of state said while puffing out his chest, that we humans must be able to subdue the nature. There was heavy rain that caused a great flood in the city of his residence. He was forced to be stretchered in order to get out of his palace because the car that would carry him could not run in the flood and the engine could not turn on. People say; "Our king said he wanted to subdue nature, now apparently he is the one who has to submit to nature!" (Hamka 1982b, vol. 1, 151).

The above story is used as a reflection to Sukarno's administration, that, according to Hamka, affiliates to communism. In some cases, Hamka depicts Sukarno implicitly. When Hamka refers to other head of State other than Sukarno, he would have mentioned his/her by name.

There is one other allusion that Hamka makes in interpreting this verse, i.e. communist failure in an attempt at disbanding the Islamic Student Association (HMI). "There is a story," Hamka says, "that a communist leader who does not believe in God once said in a meeting: "If you do not move to disperse the Islamic Student Association, it is better to exchange your pants for a sarong (becoming a woman).' The day after he said that vehemently, the communists held a rebellion to seize power and killed six generals. Apparently, their revolt only lasted for one day and only in the afternoon could be thwarted. So, that arrogant communist leader was forced to flee out of the city, turned out they were the ones who exchanged pants for sarong (Hamka 1982b, vol. 1, 151). 
Still, in the framework of the interpretation of the verses of God's power, Hamka elsewhere interprets Q.S. Âli 'Imrân [3]: 160 as God's message to humans that human being should believe that God would indeed provide help over them.

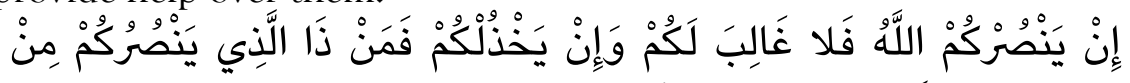

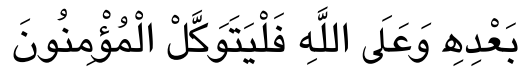

"If God helps you (believers), no one can overcome you; If He forsakes you, who else can help you? Believers should put their trust in God."

This verse conveys two messages. First, when God helps someone, no one can defeat him, and if God defeats someone, no one can help him. Second, for the power of God, humans have to put their trust in God in all their efforts and plans (al-Qurțubî 2006, vol. 5, 386).

The awareness of the existence of God and the trust upon Him are what missing from communism-they do not believe in all of that. That is Hamka's criticism against communism. The event of the September 30th Movement was one of the examples that reflected communist mistrust of God, that eventually led them to destruction. Hamka writes in his commentary:

"The closest example is the defeat and failure of the communists in Indonesia in their attempt at seizing power (coup) on 30 September 1965. They were sure that their intentions would succeed and they would surely win. (That was) because for several years they had been preparing (for it) while exacerbating the situation. And us, the opposing party, have started to doubt about God's help. There remains only a small group of believers who remain faithful and submit to God, assuring, that one time, God will intervene, even though they do not know any more where God's help will come from. Finally, the communists acted; they killed six generals. Satan's persuasion came to them. (That) this particular general (should be) killed first, only then the others would be easily dealt with. Nevertheless, because they did not trust in God and their intentions were purely evil, their plan lasted only for a day. In the evening, the situation was under control by General Suharto with God's help" (Hamka 1982b, vol. 2, 138).

In interpreting the phrase "fa man dha-lladhî yansurukum min ba 'dih (who else can help you), Hamka writes as follows: 
"The head of state which was expected to condemn them, in fact, defended them. The people, especially those who believe in Allah, were given by God the power of attacking those godless people ... finally, the communists suffered a substantial lost ... Sukarno, with all of charisma, power and influence he had, made his every effort to help the communists. He arranged all the possible strategies. However, the result was not only were the communists destroyed, the authority of Sukarno who defended them was also destroyed by God. How can we not believe that God exists? Some events in this world give us a clue, that human efforts trying to manipulate the power of God always fail "(Hamka 1982b, vol. 2, 138-9).

Another interpretation of resistance occurs as well when Hamka contextualises the meaning of Q.S. al-Baqarah [2]: 204-207.
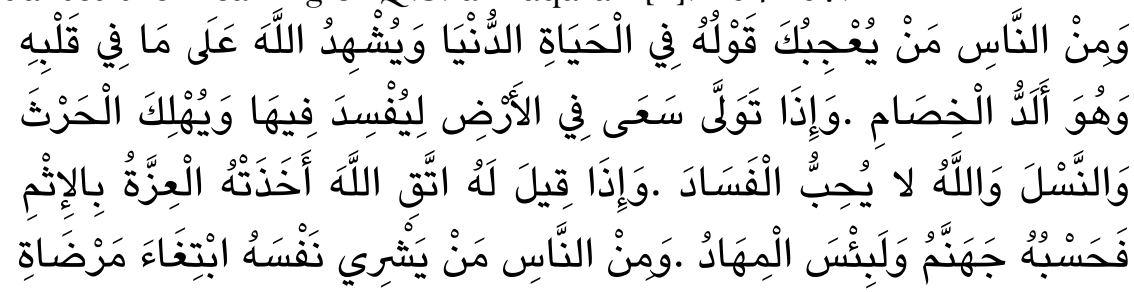

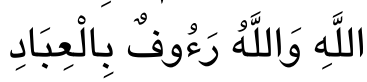

"There is (a kind of) man whose views on the life of this world may please you (Prophet), he even calls on God to witness what is in his heart, yet he is the bitterest opponents. When he leaves, he sets out to spread corruption in the land, destroying crops and livestock-God does not like corruption. When he is told, 'Beware of God,' his arrogance leads him to sin. Hee is enough for him: a dreadful resting place. But there is also a kind of man who gives his life away to please God, and God is most compassionate to His servants."

The textual meaning of this verse is about a group of people who uses sweet words to deceive others. Hamka said that the verse talks about hypocrite people. Hypocrites are those who talk nicely, making people interested in their words. They twirl the tongue according to circumstances.

Sukarno, according to Hamka, possessed this character. With a fairly lengthy description, Hamka explicitly recounted his conflict with Sukarno and his followers, as he wrote:

"Because what he made as the guideline was not the truth nor the name of God-that only passed in his mouth-but the glory for himself, the benefits 
he was trying to gain. He managed different plans to the will of God, but to hide his evil intentions, he talked nicely. The more evil their plan was, the more beautiful they were talking. Sweet talks were what often broke the elbows of people who wanted to oppose their injustice. The plan was of self-pride. The rules of God, when considered detrimental to his plans, will undoubtedly be obstructed and despised. Therefore, religion was used as long as benefit them ... They deceived people entrusted power to him with persuasive rhetoric, making people complacent with his speech, even though what they are aiming for was getting farther and farther away. It was easy for them to say (the name of) God ... This was what a dictator ruling or an individual cult did. Every time (he) only showed off the power. Almost every day the people were mobilized to watch the greatness of "your majesty", applauding the speech of "your majesty" so that the gardens were left behind and the fields are abandoned" (Hamka 1982b, vol. 1, 148-9).

This line of statements from Hamka concerns with the communists in Indonesia, i.e. Sukarno and his followers. Hamka's words such as "religion was used as long as benefited him" and "it was easy for them to say (the name of) God" indicates the character of communists of Indonesia. Some of the Indonesian communists were Muslims, and some have extensive knowledge of Islamic disciplines.

In addition to that, Hamka explicitly denounced Sukarno by explaining his dictatorial leadership character that led to an individual cult. Every time he showed off the power using his rhetorical skill. Even more, the people were mobilized to see the performance. If we look at historical literature, Sukarno was indeed a great orator. Many people were amazed by his words.

Hamka conveys that, when this dictator ruler was reprimanded, he would be angry, and those who criticize him would be considered as traitors. This was what happened between Hamka and Sukarno. The conflict between the two culminated when Hamka was jailed on charges of subversion (Pink 2010a, 59). Hamka writes:

"And if the criticism is issued (against them), the authority and the dictator would be angry; he would also accuse; accuse of traitors to the state, accuse of subversion, being accomplices of foreign (countries) or being counter-revolutionary. Dozens and even hundreds of ulamas have been charged from time to time, for their bravery to raise their voices to say what is right and rebuke what is wrong" (Hamka 1982b, vol. 1, 153). 
Hamka also mentions that those who would harm Muslims with their deception, as mentioned in other verses, i.e. Q.S. Âli 'Imrân [3]: 120, are the communists. He states that communist deception uses sweet words even by saying the word "assalâmu 'alaykum" when speaking or meeting with Muslims (Hamka 1982b, vol. 2, 71). Therefore, Hamka advises in his interpretation that one would not trust the communists even though they said the shahâda.

The above message was conveyed by Hamka when interpreting another verse, i.e. Q.S. al-Nisâ' [4]: 94. This verse textually reminds believers who were preparing for jihâd in the land of the enemy to be considerate in the sense that they should not kill people randomly. The reason behind this warning was that there was a possibility that, even in enemy lands, they would meet Muslims. They should not be killed just because Muslim forces expect loot. One of the signs that they were believers was when they say greetings, as stated in the verse.

To be more evident about the verse, Hamka elaborates on the asbâb

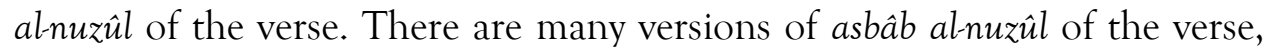
one of which is transmitted by al-Bukhârî. Al-Bukhâri reported: "During an attack on enemy land, there was a man with his belongings. The person immediately said: "assalâmu 'alaykum." Nevertheless, the patrol ignored the man's greetings and killed him. This was conveyed to Rasulullah PBUH, and his property was handed over to him. Upon this event, the verse was revealed, denouncing Muslims force for their wish of loot" (Dahlan and Alfarisi 2000, 158).

However, according to Hamka, God's warning showed by this verse does not apply to the communists because they do not have religions. If a communist says the shahâda when they are arrested, it is undoubtedly just deceit. This kind deceit of communist happened in Indonesia in 1965 when Muslims in several regions exterminated the communists; there were some of them who recited the shahâda when they were about to be killed. Nevertheless, most of their shahâda was not trusted. Hamka firmly states: "There is nothing in the history of this world, that there is one community is more evil than the communists" (Hamka 1982b, vol. 2, 216).

Contextualisation of interpretation as Hamka's resistance to the communist regime in Indonesia occurs as well in his interpretation upon the models of infidels depicted by the Quran. For example, Hamka 
contextualises the jahiliyyah community of the Prophet Muhammad with the modern-day jahiliyyah, i.e. the communism in Indonesia; the story of Abrahah and his troops who failed to destroy the Kaaba is compared to the failure of the communist regime in Indonesia who wanted to destroy the religion of God; and the Pharaoh who inaugurated himself as God is compared to the dictator leader of Indonesian communism (Hamka 1982b, vol. 8, 97).

\section{Social Facts Forming Interpretation}

Social facts which are the product of culture are urgent references in sociology. Facts, from the perspective of sociology, are automatically prepared and conditioned by society, and their existence is always considered in relation to other social facts, which have also been socially constructed (Latief 2008). The following are social facts that emerged in the context of communism in Indonesia, especially those which relate to the Sukarno regime, that helped construct the formation of Hamka's resistance commentary against the communist regime.

According to Donald Hindley, Sukarno first became acquainted with communism towards the end of 1955, and eventually joined communism in 1957. There were two factors that led Sukarno to join communism: his struggle to maintain the dominant position in politics and his hopes for completing the revolution (Hindley 1962, 1). Sukarno wanted grassroots to support communist ideas. He also sought to unite communist ideology with nationalism and religion (Maiyer 1987, 22). Sukarno's thoughts and generally that of communism all are originated or influenced by the ideas of Lenin and Mao (Maiyer 1987, 27).

The relationship between Sukarno and the communists became stronger after the PKI received full support from Sukarno. This support made the PKI grew bigger. During a meeting on December 13rd 1963, D.N. Aidit, as the chairman of PKI said that the number of PKI members was increasing, reaching 2.5 million. After one year, in 1964, D. N. Aidit claimed that the number of PKI members had increased to more than 3 million; 2 million are young people, 3.2 million from the merchants' group, 1.75 million women, and 7 million from peasants. The PKI claimed that they controlled $17.5 \%$ of the total population of Indonesia (Pauker 1967, 1058). In 1950 the PKI was only a small party, but succeeded in influencing the marginal groups in Jakarta, both politically and culturally (Maiyer 1987, 7). 
On the other hand, Muslims who were represented by Islamic parties and Islamic organizations often conflicted with the communists. Masyumi was an Islamic party whose members are cadres of several Islamic organizations that strongly opposed the pro-communism and pro-PKI Sukarno's leadership. The Masyumi Party was the toughest opponent of the PKI during the election (Van Bruinessen 2002, 21). In 1958, in the sessions of the Constituent Assembly meetings-the legislative council that was tasked by the 1955 general election to make the constitution, there were serious debates about the basis of the state. Some advocated Islamic state, represented by Islamic parties such as the Masyumi, Nahdlatul Ulama, Perti, and Sarekat Islam. Some others proposed to keep Pancasila, represented by the Nationalist, Communist, Socialist, Christian and Catholic parties. Hamka itself was one of the constituent members belonging to the proponents of the Islamic state. The prolonged and exhausting debates failed to achieve consensus, eventually terminated by the presidential decree that commanded, among others, the return to the 1945 Constitution, the establishment of Guided Democracy, and the dissolution of the Constituent Assembly (Shobahussurur 2009, 234-5).

Conflicts between communist groups and Islamic organizations occurred as well in preceding history. After Indonesia's independence, the communists began to enter the city of Yogyakarta, especially Kota Gede. Muhammadiyah, which at that time was one of the Islamic organizations besides Nahdlatul Ulama who opposed communism, decided to join the Masyumi Islamic party, a decision taken in order to resist the communist ideology (Sulistiyanto 2006, 259).

Although the communists encountered oppositional moves from Islamic organizations and parties, the PKI continued to overgrow. They succeeded in building a movement strategy by approaching the authorities, including influential ulamas. One of the strategies pursued by the PKI was to build closeness and relations with important actors of nationalist antiIslam groups, including PNI and president Sukarno (Mortimer 1969, 11). The same strategy was also used when developing communism in Banten. They succeeded in recruiting local ulamas who had influences over the community. One of the great Banten scholars who joined him was Haji Achmad Chatib and his son-in-law, who was heir to the famous Banten cleric (Reid 1984, 396).

Because of this development, Muslims recorded heartbreaking conflicts with the communists. History records the bloodshed between the 
PKI and Muslims in Madiun. The PKI succeeded in occupying Madiun in East Java in September 1948, until finally the communists brutally slaughtered the kyai and santri. However, they were finally eradicated in Madiun, and this defeat brought a long-lasting wound to the PKI and triggered the GESTAPU (September 30 Movement) in 1965 (Van der Kroef 1973, 277).

In his village in Padang Panjang, Hamka had a bitter experience with regards to the communists' movements. In 1927, after Hamka returned from Mecca, he found his father in a big crisis, during which his house in Padang Panjang in 1926 was devastated by a major earthquake and his father was expelled from his school by teachers who were influenced by communist ideas (Hadler 1998, 151).

Upon the communist movements, Muslims put up a fight up to the beginning of the New Order government. The rejection of the ulama through the MUI against communist ideas and party can be seen in, among others, the content of the MUI's instruction that: (1) urges Muslims to participate in general elections in a peaceful manner and choose parties that always maintain harmony, unity, and state peace; (2) invites Muslims to choose parties that are believed to be able to fight for their aspirations and do good for all; and (3) calls Muslims in the elections to elect a party that defends the Ulama, Religion, and National Unity (Ichwan 2005, 57).

\section{The Subjectivity of Tafsir: A Criticism of Tafsîr al-Azhâr}

Hamka's work, Tafsîr al-Azhâr in Howard M. Federspiel's categorization belongs to the third generation of interpretations; it is commentaries that strive to comprehend the content of the Quran comprehensively and, therefore, contain material about the text and methodology in analyzing interpretation. Viewed from the methodological perspective, Tafsîr al-Azhâr follows tahlîli format. Federspiel also suggests that Tafsir al-Azhâr is the only one that links between Quran and contemporary events (Federspiel 1996, 48). Likewise, Fakhruddin Faiz suggests that in Tafsîr al-Azhâr, Hamka demonstrates his horizons in almost all fields of Islamic disciplines as well as enriched insight on non-religious knowledge (Faiz 2002, 73).

Nevertheless, using the lense of Nașr Hâmid Abû Zayd in reading Tafsîr al-Azhâr would reveal an element of subjectivity. According to Abû Zayd, as cited by Ichwan, there are no pure readings/interpretations (qirâ'ah 
barîah), because no knowledge stands on a vacuum, and the reader is always limited by the reader's horizon (Ichwan 2003, 85). In this case, Hamka as an interpreter is greatly influenced by his horizon in contextualizing the Quranic verses.

Hamka's subjectivity is pictured by his criticism against Sukarno, as mentioned. Comparing his works written before and after he had been prisoned would reveal that Hamka himself was an admirer of Sukarno; he even considered him as his brother. Therefore, his criticism against Sukarno was shaped by the fact that Sukarno had imprisoned him for rebel charge. It is evident at this point that Hamka imposes his subjectivity in interpreting some of the Quranic verse.

Meanwhile, Hamka's accusation that Sukarno was communist mentioned in his commentary stands on a debatable premise. Even though there are segments of people considers Sukarno communist, a significant number of others are not on the same board. Those who object the accusation stands on Sukarno's expression, emphasizing that he was not a communist (Adams 2007, 50).

Hamka's expressions that Sukarno was a tyrant, authoritarian, and arrogant mentioned in his interpretation, shows his subjectivity in contextualizing the Quranic message. Sukarno was indeed a controversial figure. On the one hand, he had many supporters, but on the other hand, he also had a significant number of opponents. Some of Sukarno's ideas indicate his empathy towards the people, especially the small people. For example, the idea of Marhaenism, that later became an ideology, was Sukarno's attempt at adopting and adapting Marxist ideas, making it suitable to the Indonesian context. The commitment of Marhaenism concerning ordinary people can be seen from its teachings that emphasize the struggle of the Indonesian people who are oppressed and impoverished by capitalism, imperialism, and colonialism. In addition to that, Sukarno's marxism introduced the idea of sama rata-sama rasa (Aditjondro 2008, 25).

Likewise, Sukarno's involvement in the September 30th movement is subject to a question. Sukarno himself denied his involvement. He emphasized that his departure to Halim Air Base on October 1 was of his initiative, considering that being nearby the aeroplane would ensure mobility if something unexpected happened. He also added in his speech that he did not justify the incident and would punish anyone involved in it.

These historical facts prove that Hamka's understanding upon social facts is imposed as exegetical materials, and its inclusion runs for his 
subjectivity. Thus, Hamka's interpretation as a criticism of the sociopolitical conditions approves the view of Abû Zayd, that there is no disinterested interpretation; all interpretation is always influenced by the horizon of its authors.

\section{Conclusion}

In interpreting the Quran, Hamka contextualizes the meaning of the Quranic verse to criticize the Sukarno regime, which he considers a representation of the Communist regime in Indonesia. Whoever reads his interpretation upon the mentioned verses would find that communism occupies a great deal of Hamka's attention. For example, when interpreting Q.S. al-An'âm [6]: 33, a verse that textually speaks of the accusations of unbelievers to the Prophet Muhammad, Hamka contextualizes it with his personal experience, that Sukarno and the Communists accused him of being a liar, treacherous and betrayer of his homeland. Similarly, in interpreting Q.S. al-Baqarah [2]: 204-207, which speaks of a group of hypocrites who deceive people with persuasive rhetoric, Hamka compares them with Sukarno and Communists who deceive people with their rhetorics.

Hamka's interpretation, as investigated in this article, shows that tafsîr (Quranic exegesis) can work as social criticism. Hamka makes his interpretation as a media to criticize a particular socio-political condition during his lifetime. In doing so, he is not hesitant to impose his ide beyond the dialectical process between the verses of the Quran and reality. At this point, he positions himself as a mediator between revelation and social facts.

Additionally, this article approves the view that any text is formed by the interests of its author. In other words, there is no single text that is independent of its author's subjectivity, including the interpretation of the Quran. When doing contextualization as the final process of interpretation work, the influence of authors horizon influences the outcome of interpretation. Reflected by Tafsîr al-Azhar, Hamka's subjectivity is proven by his criticism against Sukarno and Communism. None of these criticisms was found in his writings before he was jailed. On the contrary, in previous writings, Hamka praised Sukarno a lot. 


\section{References}

Adams, Cindy. 2007. Bung Karno Penyambung Lidah Rakyat Indonesia. Trans. Samsu Hadi. Jakarta: Yayasan Bung Karno and Media Pressindo.

Aditjondro, George Junus. 2008. "Marhaenisme: Marxisme yang diterapkan di Indonesia, atau Sinkretisme Ala Sukarno?." In Ign. Gatut Saksono. Marhaenisme Bung Karno, Marxisme Ala Indonesia. Yogyakarta: Ardana Media.

Bahary, Ansor. 2015. "Tafsir Nusantara: Studi Kritis terhadap Marah Labid Nawawi al-Bantani." Ulul Albab: Jurnal Studi Islam 16(2); 176-90. DOI: http://dx.doi.org/10.18860/ua.v16i2.3179

Dahlan, H.A.A. and M. Zaka Alfarisi. 2000. Asbabun Nuzul, Latar Belakang Historis Turunnya Ayat-ayat Al-Qur'an. Bandung: CV. Penerbit Diponegoro.

Faiz, Fakhruddin. 2002. Hermeneutika Qur'ani: Antara Teks, Konteks dan Kontekstualisasi. Yogyakarta: Qalam.

Federspiel, Howard M. 1996. Kajian al-Qur'an di Indonesia. Trans. Tajul Arifin Bandung: Mizan.

Hadler, Jeffrey. 1998. "Home, Fatherhood, Succession: Three Generations of Amrullahs in Twentieth-CenturyIndonesia." Indonesia 65: 12254.

DOI: https://doi.org/10.2307/3351407

Hakim, Lukman Nul. 2018. "Budaya Tutur Dalam Tafsir Melayu: Studi Wacana Peribahasa Melayu Dalam Tafsir Al-Azhar Karya Hamka." Intizar 24(1): 19-36.

DOI: https://doi.org/10.19109/intizar.v24i1.1968

Hamka. 1981. Said Jamaluddin Al-Afghany. Jakarta: Bulan Bintang.

Hamka. 1982a. Ayahku. Jakarta: Pustaka Panjimas.

Hamka. 1982b. Tafsîr al-Azhâr. Jakarta: Pustaka Panjimas.

Hamka. 1983. Tasauf Modern. Jakarta: Pustaka Panjimas.

Hamka. 2002. Dari Hati ke Hati. Jakarta: Pustaka Panjimas. 
Hamka, Irfan. 2013. Ayahku, Kisah Buya Hamka. Jakarta: Penerbit Republika.

Hindley, Donald. 1962. "President Sukarno and the Communists: The Politics of Domestication." The American Political Science Review 56(4): 915-26.

DOI: https://doi.org/10.2307/1952793

Ichwan, Moch Nur. 2003. Meretas Keserjanaan Kritis al-Qur'an: Teori Hermeneutika Nashr Hamid Abu Zayd. Jakarta: Teraju.

Ichwan, Moch. Nur. 2005. "Ulamâ', State and Politics: Majelis Ulama Indonesia after Suharto." Islamic Law and Society 12(1): 45-72.

DOI: https://doi.org/10.1163/1568519053123867

Ilyas, Yunahar. 2006. Kesetaraan Gender dalam al-Qur'an: Studi Pemikiran Para Mufassir. Yogyakarta: Labda Press.

Ismatulloh, A.M. 2015. "Metode Dakwah Dalam al-Qur'an: Studi Penafsiran Hamka QS. an-Nahl: 125." Lentera 17(2): 155-69.

DOI: https://doi.org/10.21093/lj.v17i2.438

Jamarudin, Ade, H. Asmal May, and Ofa Ch Pudin. 2019. "”The Prospect of Human in The Exegetical Work: A Study of Buya Hamka's Tafsir al-Azhar." Ulumuna: Journal of Islamic Studies 23(1): 24-47.

DOI: https://doi.org/10.20414/ujis.v23i1.360

Keener, R. Michael. 2002. "Indonesian Movements for the Creation of a 'National Madhhab'." Islamic Law and Society 9(1): 83-155.

DOI: https://doi.org/10.1163/156851902753649298

al-Khawârizmî, Abû al-Qâsim Jâr Allâh Maḥmûd ibn 'Umar al-Zamakhsharî. 2009. al-Kashshâf 'an Haqấ'iq al-Tanzîl wa 'Uyun al-Aqâwîl Fî̀ Wujûh al-Ta'wîl. Beirut: Dâr al-Ma'rifah.

Kusnadi, Kusnadi. 2015. "Nuansa-Nuansa Sastra dalam Tafsir Hamka." Wardah 16(1): 1-13.

Latief, Mohamad. 2018. "The Sociology of Knowledge: A Preliminary Analysis of The Sociological Approach to The Development of Islamic Religious Sciences.” Ulul Albab: Jurnal Studi Islam 19(2): 272-89.

DOI: http://dx.doi.org/10.18860/ua.v19i2.5597 
Maier, Hendrik M. J. 1987. "Chairil Anwar's "Heritage: The Fear of Stultification": Another Side of Modern Indonesian Literature." Indonesia 43: 1-29.

DOI: https://doi.org/10.2307/3351207

Mortimer, Rex. 1969. "Class, Social Cleavage and Indonesian Communism." Indonesia 8: 1-20.

DOI: https://doi.org/10.2307/3350667

Pauker, Ewa T. 1964. "Has the Sukarno Regime Weakened the PKI?.” Asian Survey 4(9): 1058-70.

DOI: https://doi.org/10.2307/2642398

Pink, Johanna. 2010a. "Tradition, Authority and Innovation in Contemporary Sunnî Tafsîr: Towards a Typologyof Qur'an Commentaries from the Arab World, Indonesia and Turkey." Journal of Qur'anic Studies 12(1-2): 56-82.

DOI: https://doi.org/10.3366/jqs.2010.0105

Pink, Johanna. 2010b. "Tradition and Ideology in Contemporary Sunnite Qur'ânic Exegesis: Qur'ânic Commentaries from the Arab World, Turkey and Indonesia and their Interpretation of Q 5:51." Die Welt des Islams 50(1): 3-59.

DOI: https://doi.org/10.1163/157006010X489801

al-Qurțubî, Abû 'Abd Allâh Muḥammad ibn Aḥmad ibn Abî Bakr. 2006.

Tafsîr al-Qurtubî al-Jâmi al-Ahkâm al-Qur'ân wa al-Mubayyin Limâ Tadammanahu min al-Sunnah wa Âyi al-Furqân. Beirut: Mu'assasah alRisâlah.

Reid, Anthony. 1984. "Sickle and Crescent: The Communist Revolt of 1926 in Banten by Michael C. Williams." Journal of Southeast Asian Studies 15(2): 393-4.

DOI: https://doi.org/10.1017/S0022463400012662

Shobahussurur, Shobahussurur. 2009. "Relasi Islam dan Kekuasaan dalam Perspektif Hamka.” Asy-Syir'ah 43(1): 231-45.

DOI: http://dx.doi.org/10.14421/asy-syir'ah.2009.\%25x

Sulistiyanto, Priyambudi. 2006. "Muhammadiyah, Local Politics and Local Identity in Kotagede." Sojourn: Journal of Social Issues in Southeast Asia 21(2): 254-70. 
DOI: https://doi.org/10.1355/sj21-2f

Syamsuddin, Sahiron. 2009. Hermenetuika dan Pengembangan Ulumul Qur'an. Yogyakarta: Pesantren Nawasea Press.

al-Ṭabarî, Muhammad ibn Jarîr. 1994. Jâmi' al-Bayân 'an Ta'wîl Âyi alQur'ân. Beirut: Mu'assasah al-Risâlah.

Ulya, Ulya. 2015. "Hubungan Kekuasaan-Pengetahuan Dalam Pewacanaan Ulul Al-Amr QS. An-Nisa' (4) Pada Tafsîr Al-Azhâr: Memotret Diskusi Negara Indonesia Tahun 1955-1966.” Dissertation. Universitas Islam Negeri Sunan Kalijaga Yogyakarta.

Van Bruinessen, Martin. 2002. "Genealogies of Islamic radicalism in postSuharto Indonesia.” South East Asia Research 10(2): 117-54.

DOI: https://doi.org/10.5367/000000002101297035

Van der Kroef, Justus M. 1973. “Sukarno's Indonesia." Pacific Affairs 46(2): 269-88.

DOI: https://doi.org/10.2307/2756173

Zulaiha, Evi. 2017. "Tafsir Kontemporer: Metodologi, Paradigma dan Standar Validitasnya." Wawasan: Jurnal Ilmiah Agama dan Sosial Budaya 2(1): 81-94.

DOI: https://doi.org/10.15575/jw.v2i1.780 